\title{
SELF-COMPATIBILITY INHERITANCE IN TOMATILLO (PHYSALIS IXOCARPA BROT.)
}

\author{
Juan MULATO-BRITO, Aureliano PEÑA-LOMELÍ, \\ Jaime SAHAGÚN-CASTELLANOS, Clemente VILLANUEVA-VERDUZCO, \\ José DE JESÚS LÓPEZ-REYNOSO \\ Departamento de Fitotecnia. Universidad Autónoma Chapingo \\ Chapingo, Edo. de México. C.P. 56230, México
}

Received: January 2, 2007; Accepted: November 14, 2007

\begin{abstract}
Summary
One of the main limiting factors to improve tomatillo is the presence of self-incompatibility which has been reported to be gametophytic. In an early research, a self-compatible plant was found in the Rendidora landrace and this allowed us to investigate the inheritance of self-compatibility gene (s) in tomatillo. The following crosses were performed: self-compatible $\mathrm{x}$ selfincompatible, self-compatible $\mathrm{x}$ self-compatible and self-incompatible $\mathrm{x}$ selfincompatible and their respective reciprocal crosses. Segregation ratios on selfcompatibility versus self-incompatibility in their offspring indicate that selfcompatibility is not inherited via cytoplasm, so the responsible gene is located in chromosomes. The inheritance of self-compatibility is due to a single dominant gene $\left(\mathrm{S}_{\mathrm{c}}\right)$ which is a mutation at the $\mathrm{S}$ locus. Self-compatible individuals are strictly heterozygous $\left(\mathrm{S}_{\mathrm{c}, 4}\right)$ and finally, the self-compatibility allele $\left(\mathrm{S}_{\mathrm{c}}\right)$, in the male side $\left(S_{c, 4}\right)$, seems to be non functional when self-pollinating the $S_{c, 4}$ stigma. A single gene controlling stem pubescence was also found.
\end{abstract}

key words: tomatillo, Solanaceae, self-compatibility gene, stem pubescence gene, inheritance

\section{INTRODUCTION}

One of the main limiting factors to improve tomatillo (Physalis ixocarpa Brot.) is the presence of self-incompatibility (SI) (Menzel 1951) which has been reported to be gametophytic (Pandey 1957). SI is the inability of a fertile hermaphrodite seed plant to produce zygotes after self-pollination (Lundqvist 1964, Williams 1965, de Nettancourt 1977). More than 3000 plant species exhibit self-incompatibility (East 1940). There have been reported two selfincompatibility systems in plants: heteromorphic and homomorphic (Williams 1965). The homomorphic system is either gametophytic (East \& Mangelsdorf 1925) or sporophytic (Hughes \& Babcock 1950, Gerstel 1950).

Corresponding author: e-mail: mulatoju60@yahoo.com.mx (C) Copyright by RIVC 
In gametophytic systems pollen genotype incompatibility is determined by the haploid genome of the pollen grains, and these systems are always multiallelic since the minimum number of permissible alleles at one locus is three (Richards 1986). An incompatible mating occurs when an $\mathrm{S}$ allele is transported by a haploid pollen grain which matches any other $\mathrm{S}$ alleles in the diploid style. A compatible mating occurs when the $\mathrm{S}$ allele which is carried out by haploid genome of the pollen grain is different from $\mathrm{S}$ alleles in the diploid tissue of the style. $\mathrm{S}$ alleles exhibit neither any kind of dominance nor any other inter-allelic interaction (Williams 1965). In most of the species, SI is controlled by a single locus but in some species it may be regulated by two loci (Pandey 1960) with complementary effects (Williams 1965). In a sporophytic system the incompatibility reaction is determined by the genotype of the diploid style and $\mathrm{S}$ alleles may exhibit hierarchical dominance. Therefore, if a $S_{1}$ allele is dominant over $S_{2}$, then all pollen grains of a $S_{1,2}$ plant will react as if they were $S_{1}$ pollen grains, so $S_{2}$ pollen grains will be able to pollinate styles which contain $S_{2}$ alleles (Wiliams 1965).

The presence of self-compatible plants derived from self-incompatible populations has been reported a long time ago (Kakizaki 1930, Bateman 1954, Cipar et al. 1964). Brassica campestris is one example where self-compatibility (SC) allele $S^{c}$ is recessive to the two alleles in both pollen and stigma; it is a case where SC was ascribed to a mutation at the S locus (Zuberi et al. 1981). Also in tomato (Lycopersicon peruvianum) SC has been originated by a mutation at the S locus (Kowyama et al. 1994). In some other species SC is due to a single dominant gene: Citrus (Soost 1969), Rubus (Keep 1985) and Prunus (Iezzoni et al. 1990). In potato, SC is controlled by a single dominant gene independent of the $\mathrm{S}$ locus with sporophytic action and after 8 selfing generations, $\mathrm{SC}$ has been maintained in a heterozygous condition implying that dominant homozygotes might be associated with lethality (Hosaka \& Hanneman 1998).

When a genus contains SC as well as SI species and in natural genetic populations contains self-compatible and self-incompatible individuals, it is believed that the SC forms derive from the SI ones (Tsukamoto et al. 1999, Kondo et al. 2002, Onus \& Pickersgill 2004). Nevertheless, SC individuals, originated from species completely SI, could appear either spontaneously or artificially but in both cases such individuals can be derived by losing the function of the S locus genes or by external factors like polyploidisation (Husband \& Schemske 1997, Cook \& Soltis 2000, Stone 2002, Wünsh \& Hormaza 2004, Takayama \& Isogai 2005). Regarding polyploidy, a recent study has demonstrated that polyploidy is neither strongly related to the presence nor an increase of SC in angiosperm plants (Mable 2004).

Therefore, in order to approach plant breeding hybridization techniques for tomatillo, it would be desirable to search for self-compatibility genes which have not been reported in literature to be present either in landraces or in improved varieties. In a previous research, it was possible to discover, for the first time, the presence of self-compatibility genes. This gene (s) was found out in the Rendidora landrace accession 1 (Rendidora, CHF1-Chapingo) which was 
developed by mass selection. According to this, the investigation has the aim of studying the inheritance of self-compatibility gene (s) mentioned above. Research is based on the hypothesis that self-compatibility may be controlled by single genes and their inheritance can be determined by making some proper crosses.

\section{MATERIALS AND METHODS}

This research was performed in the greenhouse facilities of the Plant Agriculture Department of the University of Guelph, Canada and Departamento de Fitotecnia de la Universidad Autónoma Chapingo, Mexico. Seed was obtained from a tomatillo self-compatible plant which was discovered in the greenhouse facility of the Plant Agriculture Department of the University of Guelph Canada. Such a plant came from the Rendidora, CHF1-Chapingo variety. A series of crosses were performed and went under the following scheme (in all cases 10 flowers per plant were hand pollinated and 100 individual issue plants were evaluated, except in crosses D3, D4 and R4; see below) : a) Self-compatible $\mathrm{x}$ self-incompatible (direct=D1), two unrelated plants were selected, one selfcompatible plant $\left(\mathrm{S}_{1}\right)$ was used as a female and male flowers were taken from a self-incompatible plant (Milpero landrace); b) Self-incompatible x selfcompatible (reciprocal of $\mathrm{D} 1=\mathrm{R} 1$ ), the same two plants used in D1 were crossed reciprocally; c) Self-compatible $\mathrm{x}$ self-compatible (direct=D2), two selfcompatible sister plants were selected, one as female and the other one as male; d) Self-compatible x self-compatible (reciprocal of D2=R2); e) Self-compatible $\mathrm{x}$ self-incompatible (direct=D3), two $\mathrm{S}_{2}$ sister plants were crossed, only 65 offspring individuals were evaluated due to less seed was obtained; f) Selfincompatible $x$ self-compatible (reciprocal of $D 3=R 3$ ), the same two sister plants selected in D3 were crossed reciprocally; g) Self-incompatible x selfincompatible (direct $=\mathrm{D} 4)$, two sister self-incompatible plants were crossed with not success and not any issue individual was evaluated; $h$ ) Self-incompatible $x$ self-incompatible (reciprocal of $\mathrm{D} 4=\mathrm{R} 4$ ) the same two plants were crossed reciprocally with not success; i) Recurrent selfing (generations $S_{1}$ and $S_{2}$ ), the $S_{1}$ generation was obtained in Canada by selfing the original self-compatible plant. 150 individuals were planted into a greenhouse, when seedlings were at first flower developmental stage they were covered by using nylon bags which had little holes to avoid crosspollination, segregation ratios for self-compatibility in this generation were taken by considering the number of self-compatible and self-incompatible individuals; the $\mathrm{S}_{2}$ generation was generated in Mexico, by mixing seed from six self-compatible $\mathrm{S}_{1}$ plants, 66 individuals were established under the same conditions as in $\mathrm{S}_{1}$ generation, the criterion to measure segregation ratios for self-compatibility was the same as in $S_{1}$. 


\section{RESULTS}

Offspring of all crosses, except cross D3, D4 and R4, segregated almost in the same 1/2:1/2 ratio for self-compatibility and self-incompatibility (Table 1). Segregation ratio was similar as in direct crosses as in the reciprocal ones. Except in D3, D4 and R4; i.e. D1, R1, D2, R2 and R3 produced $1 / 2$ selfcompatible and $1 / 2$ self-incompatible plants while D3 showed $100 \%$ of selfcompatible plants and D4 \& R4 did not produced any offspring.

Table 1. Chi-square test for segregation ratios for self-compatibility gene in the offspring of the crosses

\begin{tabular}{lcccccccc}
\hline \multicolumn{1}{c}{ Cross } & $\mathrm{D} 1$ & $\mathrm{R} 1$ & $\mathrm{D} 2$ & $\mathrm{R} 2$ & $\mathrm{D} 3$ & $\mathrm{R} 3$ & $\mathrm{D} 4$ & $\mathrm{R} 4$ \\
\hline $\begin{array}{l}\text { Self- } \\
\text { compatible }\end{array}$ & 53 & 48 & 49 & 54 & 65 & 54 & 0 & 0 \\
$\begin{array}{l}\text { Self- } \\
\text { incompatible }\end{array}$ & 47 & 52 & 51 & 46 & 0 & 46 & 0 & 0 \\
$\begin{array}{l}\text { Ratio } \\
\chi^{2}\end{array}$ & $\begin{array}{c}0.53: 0.47 \\
0.36^{*}\end{array}$ & $\begin{array}{c}0.48: 0.52 \\
0.16^{*}\end{array}$ & $\begin{array}{c}0.49: 0.51 \\
0.04^{*}\end{array}$ & $\begin{array}{c}0.54: 0.46 \\
0.64 *\end{array}$ & $\begin{array}{c}1: 0 \\
0.00\end{array}$ & $\begin{array}{c}0.54: 0.46 \\
0.64 *\end{array}$ & $0: 0$ & 0.0 \\
\hline
\end{tabular}

$\mathrm{D}, \mathrm{R}=$ Direct and reciprocal cross, respectively.

$*=$ Null hypothesis is not rejected.

$S_{1}$ and $S_{2}$ offspring showed a segregation ratio of $1 / 2$ for self-compatibility and $1 / 2$ for self-incompatibility (Table 2) what are the same results as in crosses D2 and R2, mentioned before.

Table 2. Chi-square test for segregation ratios for self-compatibility $\left(\mathrm{S}_{\mathrm{c}}\right)$ and pubescence of the stem (pub+) of tomatillo in $S_{1}$ and $S_{2}$ generations

\begin{tabular}{lccccccc}
\hline Generation & $\mathrm{S}_{\mathrm{c}, 4}$ & $\mathrm{~S}_{4,4}$ & $\chi^{2}$ & pub+ pub+ & pub+ pub- & pub- pub- & $\chi^{2}$ \\
\hline $\mathrm{S}_{1}$ & 77 & 73 & & 39 & 79 & 32 & \\
Ratio & 0.51 & 0.49 & $0.11^{*}$ & 0.26 & 0.53 & 0.21 & $1.07^{*}$ \\
$\mathrm{~S}_{2}$ & 36 & 30 & & 20 & 38 & 17 & \\
Ratio & 0.55 & 0.45 & $0.27^{*}$ & 0.27 & 0.51 & 0.22 & $0.25^{*}$ \\
\hline
\end{tabular}

$*=$ Null hypothesis is not rejected

Finally, it was possible in $\mathrm{S}_{1}$ and $\mathrm{S}_{2}$ generations to identify and observe the segregation of a particular gene which controls pubescence of the tomatillo stem. As in self-compatibility gene, the inheritance of tomatillo stem pubescence has not been reported before. In this study, it was found out that such a trait is, also, controlled by a single gene but with additive effects. It is because the gene segregates in a 1:2:1 ratio (Table 2).

\section{DISCUSSION}

In D1, pollen grains of the self-incompatible plant are always carrying two self-incompatible alleles $\left(\mathrm{S}_{5}, \mathrm{~S}_{6}\right)$ and are able to pollinate the stigma $\left(\mathrm{S}_{\mathrm{c}, 4}\right)$ of the self-compatible plant, SI alleles from either male or female are coming from a 
different genetic source and as a result of this four different genotypes are possible: $1 / 4 \mathrm{~S}_{\mathrm{c}, 5} ; 1 / 4 \mathrm{~S}_{\mathrm{c}, 6} ; 1 / 4 \mathrm{~S}_{4,5} ; 1 / 4 \mathrm{~S}_{4,6}$; but in total it was obtained $1 / 2$ selfcompatible and $1 / 2$ self-incompatible individual what checks with the observed segregation ratio. The reciprocal cross (R1) produced identical results, but here the male produced two kind of pollen grains, one carrying the self-compatibility allele $\left(\mathrm{S}_{\mathrm{c}}\right)$ and the other one carrying a self-incompatibility allele $\left(\mathrm{S}_{4}\right)$. Both types of pollen grains did pollinate the stigma $\left(\mathrm{S}_{5,6}\right)$ and the same four genotypes, present in D1, were obtained and $1 / 2$ was self-compatible and $1 / 2$ was self-incompatible, as well.

As it was mentioned before, the self-compatible plant produces two kinds of pollen grains $\left(\mathrm{S}_{\mathrm{c}}, \mathrm{S}_{4}\right)$ but when they pollinate the stigma of a self-compatible plant (D2) it seems that only those pollen grains carrying the selfincompatibility allele $\left(\mathrm{S}_{4}\right)$ are able to pollinate the stigma $\left(\mathrm{S}_{\mathrm{c}, 4}\right)$. The same results were obtained in the reciprocal cross (R2), it could mean that $S_{c}$ allele in the male side is non functional when pollinating $\mathrm{S}_{\mathrm{c}, 4}$ stigma. The last two crosses (D2 y R2) can be considered as equivalent to selfing.

On the other hand, only cross D3 did produce a different segregation ratio for self-compatibility being $100 \%$ of the offspring self-compatible. These results might be explained by assuming that the genotypes of the two related plants were $S_{c, 4}$ for the female parent and $S_{4,4}$ for the male parent. In other words, it means that the male was homozygous for the self-incompatibility alleles and share such an $\mathrm{S}$ allele with the self-compatible parent due to they were derived from the same original self-compatible plant. Here, in contrast to crosses D2 and R2, it seems that pollen grains carrying $\mathrm{S}_{4}$ allele are unable to fertilize the $S_{4}$ gametes in the female side, this could explain why just a few seeds were obtained in this cross, because there is not any $S_{c}$ allele in the pollen side that interacts in a sporophytic way when it is present as in crosses D2, R2 and R3; it implies that in this species the SI system shows a combination of gametophytic and sporophytic interaction as it was mentioned early by Pandey (1957). Crosses D4 and R4 were not successful likely because the parents were homozygous for $\mathrm{S}$ alleles $\left(\mathrm{S}_{4,4}\right)$ and behaved as self-incompatible. The observed deviations in the segregation ratios from all crosses and $S_{1}$ and $S_{2}$ generations can be reasonably attributed to chance since the chi-square test failed to reject the null hypothesis (Table $1 \& 2$ ).

Therefore, segregation ratios for self-compatibility registered in crosses D1, R1, D2, R2, D3, R3, D4, R4; $S_{1}$ and $S_{2}$ generations suggest the following important aspects: a) similarity in results obtained in D1 and R1 crosses indicate that inheritance via cytoplasm of self-compatibility gene (s) is not present, it means that self-compatibility is controlled by a single gene, and not by two as reported by Pandey $(1957,1960)$ for SI, located in chromosomes, although in a recent review it is established that the S-locus consists of at least two linked transcriptional units arranged in pairs and that this multigene complex at the Slocus is inherited as one segregating unit (Takayama \& Isogai 2005); b) the genotype of the original self-compatible plant was heterozygous due to $S_{1}$ offspring was always segregating; c) self-compatibility gene is not recessive, oth- 
erwise $S_{1}$ and $S_{2}$ generations would have been entirely self-compatible; d) selfcompatibility is assumed to be determined by a mutation of the $\mathrm{S}$ locus which did produce a single dominant gene, as in other species (Soost 1969, Keep 1985, Iezzoni et al. 1990, Hosaka \& Hanneman 1998); e) self-compatibility is strictly heterozygous as it has been reported in potato (Hosaka \& Hanneman 1998); and f) self-compatibility homozygous seems not to be associated to lethality, as it has been suggested in potato (Hosaka \& Hanneman 1998), but they are not formed due to the sui generis genetic mechanism that underlies the inheritance of $\mathrm{S}$ alleles.

According to this, is clear that $\mathrm{SC}$ in tomatillo derives from a mutation on a SI individual as it was shown in tomato (Kowyama et al. 1994) and SI is the general condition in tomatillo cultivated germplasm although SC seems to be the original condition for this crop since in the wild tomatillo species SC is the common condition, but they do not inter-cross with cultivated germplasm, and this phenomenon checks with the affirmation that $\mathrm{SC}$ is the primitive condition in angiosperm plants (Bateman 1952). Nevertheless, SC individuals in tomatillo, a species completely SI, could appear spontaneously but such individuals can be derived by losing the function of the S locus genes (Stone 2002, Wünsh \& Hormaza 2004, Takayama \& Isogai 2005) but not due to an increase in polyploidy level since cytological studies performed in SC tomatillo plants did not show any polyploidy change what coincides with the findings of Mable (2004).

Regarding environmental conditions, an experiment was conducted to observe if temperature could overcome self-incompatibility, five temperatures (15, $20,25,30$ and $35^{\circ} \mathrm{C}$ ) were tested on plants of the Milpero landrace which is an entirely self-incompatible landrace. It was found that not any plant became selfcompatible besides that the observed cosegregation of the self-compatibility gene and the pubescence of the stem gene led us to conclude that selfcompatibility was a genetic trait.

To the plant breeding point of view segregation ratios obtained in $S_{1}$ and $S_{2}$ generations led us to conclude that it is not possible to develop pure lines for this particular trait (SC) but tomatillo breeders may improve the crop by developing pure lines, to produce hybrids, through different recurrent selfing generations until get enough homozygosis in most of the loci without mattering they are not be able to obtain pure lines for the self-compatibility gene.

Nevertheless, most of $S_{2}$ individual produced fruits with just a few seeds, it could mean that some gene (s) that produces a kind of parthenocarpy (seedless fruit) in tomatillo may be tightly linked to self-compatibility gene. To hybridization point of view this is undesirable because it would make more difficult to derive pure lines. But to commercial point of view this trait is particularly important because it is possible to clone the highest yielding seedless $\mathrm{S}_{2}$ individuals to develop new tomatillo varieties with high quality to produce salsa without having lot of seeds in it. 


\section{CONCLUSIONS}

Self-compatibility in tomatillo is not inherited via cytoplasm; the responsible gene is located in chromosomes; self-compatibility in tomatillo is genetically controlled by a single dominant gene $\left(\mathrm{S}_{\mathrm{c}}\right)$; self-compatible individuals are strictly heterozygous $\left(\mathrm{S}_{\mathrm{c}, 4}\right) ; \mathrm{S}_{\mathrm{c}}$ allele in the male side $\left(\mathrm{S}_{\mathrm{c}, 4}\right)$ is not functional when pollinating $\mathrm{S}_{\mathrm{c}, 4}$ stigma; pubescence of the tomatillo stem is genetically controlled by a single additive gene ( $\left.\mathrm{pub}^{+}\right)$; high pubescence corresponds to $\mathrm{pub}^{+} \mathrm{pub}^{+}$genotype, intermediate pubescence corresponds to $\mathrm{pub}^{+}$pub $\mathrm{b}^{-}$genotype and low pubescence corresponds to pub pub genotype.

\section{REFERENCES}

Bateman A.J. 1952. Self-incompatibility systems in the angiosperms. I. Theory. Heredity. 6: 285-310.

Bateman A.J. 1954. Self-incompatibility systems in the angiosperms. II. Iberis amara. Heredity. 8: 305-332.

Cipar M.S., Peloquin S.J., Hougas R.W. 1964. Variability in the expression of selfincompatibility in tuber-bearing diploid Solanum species. Am. Potato J. 41:155-162.

Cook L.M., Soltis P.S. 2000. Mating systems of diploid and allotetraploid populations of Tragopogon (Asteraceae). II. Artificial populations. Heredity. 84: 410-415.

De Nettancourt D. 1977. Incompatibility in angiosperms. Springer Verlag, Berlin.

East E.M. 1940. The distribution of self-sterility in flowering plants. Proc. Amer. Phil. Soc. 82,449 .

East E.M., Mangelsdorf P. 1925. A new interpretation of the hereditary behaviour of self-sterile plants. Proc. Nat. Acad. Sci. U.S. 24, 56.

Gerstel D.U. 1950. Self-incompatibility studies in Guayule II. Inheritance. Genetics. 45, 482.

Hosaka K., Hanneman R.E. 1998. Genetics of self-compatibility in a self-incompatible wild diploid potato species Solanum chacoense. 1. Detection of an S locus inhibitor (Sli) gene. Euphytica. 99: 191-197.

Hughes M.B., Babcock E.B. 1950. Self-incompatibility in Crepis foetida. Genetics. 35, 570.

Husband B.C., Schemske D.W. 1997. The effect of inbreeding in diploid and tetraploid populations of Epibolium angustifolium (Onagraceae): implications for the genetic basis of inbreeding depression. Evolution. 51: 737-746.

Iezzoni A., Smith H., Albertini A. 1990. Cherries. pp. 109-174. In: Genetic Resources of Temperate Fruit and Nut Crops 1. (J.N. Moore \& J.R. Bollington eds.). Int. Soc. Hort. Sci., Wageningen, The Netherlands.

Kakizaki Y. 1930. Self- and cross-incompatibilty in the common cabbage. Jpn. J. Bot. 5:133-208.

Keep E. 1985. Heterozygosity for self-incompatibility in Lloyd George red raspberry. Fuit Var. J. 39(4): 5-7.

Kondo K., Yamamoto M., Itahashi R., Sato, T. 2002. Insights into evolution of selfcompatibility in Lycopersicon from a study of stylar factors. Plant Journal. 30: 143-152.

Kowyama Y., Kunz C., Lewis I., Newbigin E., Clarke A.E., Anderson M.A. 1994. Selfcompatibility in a Lycopersicon peruvianum variant (LA2157) is associated with lack of style S-RNase activity. Theor. Appl. Genet. 88: 859-864. 
Lundqvist A. 1964. The nature of the two loci incompatibility system in grasses. IV. Interaction between the loci in relation to self-compatibility in Festuca pratensis Huds. Hereditas. 52: 221-234.

Mable B.K. 2004. Polyploidy and self-compatibility: is there an association? New Phytol. 162: 803-811.

Menzel M.Y. 1951. The cytotaxonomy and genetics of Physalis. Proc Amer. Phil. Soc. 95:132-183.

Onus A.N., Pickersgill B. 2004. Unilateral incompatibility in Capsicum (Solanaceae): occurrence and taxonomic distribution. Ann. Bot. 94: 289-295.

Pandey K.K. 1957. Genetics of self-incompatibility in Physalis ixocarpa Brot.- A new system. Amer. J. Botany. 44:879-887.

Pandey K.K. 1960. Self-incompatibility system in two Mexican species of Solanum. Nature. Lond., 185, 483.

Richards A.J. 1986. Plant breeding systems. Allen and Unwin, London.

Soost R.K. 1969. The incompatibility gene system in citrus. pp: 189,190. In: Proc. of the First Intl. Citrus Symp. 1, (H.D. Chapman ed.).University of California, Riverside, $\mathrm{CA}$.

Stone J.L. 2002. Molecular mechanisms underlying the breakdown of gametophytic self-incompatibility. Quart. Rev. Biol. 77(1): 17-32.

Takayama S., Isogai A. 2005. Self-icompatibility in plants. Annu. Rev. Plant Biol. 56: 467-489.

Tsukamoto T., Ando T., Kokubun H., Watanabe H., Masada M., Zhu X., Marchesi E., Kao T. 1999. Breakdown of self-incompatibility in a natural population of Petunia axilaris (Solanaceae) in Uruguay containing both self-incompatible and selfcompatible plants. Sex Plant Reprod. 12: 6-13.

Williams W. 1965. Genetical principles and plant breeding. Blackwell Scientific Publications. Oxford, England. 527 pp.

Wünsch A., Hormaza J.I. 2004. Genetic and molecular analysis in Cristobalina sweet cherry, a spontaneous self-compatible mutant. Sex Plant Reprod. 17: 203-210.

Zuberi M.I, Zuberi S., Lewis D. 1981. The genetics of incompatibility in Brassica. I. Inheritance of self-compatibility in Brassica campestris L. var. Toria. Heredity. 46:175-190.

\section{DZIEDZICZENIE SAMOZGODNOŚCI \\ U MIECHUNKI POMIDOROWEJ (PHYSALIS IXOCARPA BROT.)}

Jednym z głównych czynników ograniczających w hodowli miechunki pomidorowej jest samoniezgodność, określona w literaturze jako gametofityczna. We wcześniejszych badaniach znaleziono roślinę samozgodną w odmianie lokalnej Rendidora i to pozwoliło nam na badania genu samozgodności (s) w tym gatunku. Dokonano następujących krzyżowań: samozgodne x samoniezgodne, samozgodne x samozgodne i samoniezgodne $x$ samoniezgodne, a także odpowiednie odwrotne krzyżowania. Stosunek samozgodności do samoniezgodności wśród potomstwa otrzymanego z tych krzyżowań wskazuje, że dziedziczenie samozgodności nie jest cytoplazmatyczne, a więc odpowiedni gen znajduje się w chromosomach. Za dziedziczenie samozgodności odpowiada jeden dominujący gen $\left(\mathrm{S}_{\mathrm{c}}\right)$, który stanowi mutację w pozycji S. Osobniki samozgodne są ściśle heterozygotyczne $\left(\mathrm{S}_{\mathrm{c}, 4}\right)$. Allel samozgodności $\left(\mathrm{S}_{\mathrm{c}}\right)$ po stronie męskiej $\left(\mathrm{S}_{\mathrm{c}, 4}\right)$ wydaje się być niefunkcjonalny, gdy następuje samozapylenie znamienia $S_{c, 4}$. Stwierdzono również, że inny pojedynczy gen kontroluje włoskowatość łodygi u miechunki pomidorowej. 